Agricultural Journal 7 (6): 382-387, 2012

ISSN: $1816-9155$

(C) Medwell Journals, 2012

\title{
The Indus Water Distribution in Sindh, Pakistan: Management, Impacts and Conflicts
}

\author{
${ }^{1,2}$ Habibullah Magsi and ${ }^{3}$ Salman Atif \\ ${ }^{1}$ UMR SAD-APT, INRA AgroParisTech 16, rue Claude Bernard, 75005 Paris, France \\ ${ }^{2}$ Department of Agricultural Economics, Sindh Agriculture University, Tando Jam, Pakistan \\ ${ }^{3}$ UMR Prodig, Universite Paris 7 Denis Diderot, Paris, France
}

\begin{abstract}
Little attention has been devoted to the water projects instituted to store and divert Indus water in the upper Indus basin which are causing water shortage in Sindh province of Pakistan. The water shortage further results in economic, social and ecological problems which became a source of conflict between provinces of the country. The study emphasizes on the mismanagement and flawed water distribution policies which are germinating inter-provincial social-conflicts. The study is in descriptive in parts where researchers tried to evaluate shortage of water in Sindh province with respect to planning, storage and distribution of Indus water and their impacts on the economic, social and environmental life of the province. Then researchers evaluate the impacts of water conflicts, especially in downstream riparian where Indus delta is moving towards an ecological disaster and famine like situation. Finally researchers recommend resolution measures. Therefore, the attention to such conflicts, their resolution and prevention is an important area for research and policy development.
\end{abstract}

Key words: Indus river, water conflicts, policy, Sindh, Pakistan, France

\section{INTRODUCTION}

Water is not however, equally or even equitably distributed to every one but the gap between demand and supply of water across regions has increased the level of interprovincial and trans-boundary conflicts in Pakistan. In this regard, immense literature is available on the Pakistan-India water frictions and accords on Indus river (World Bank, 2005; Colombi and Robert, 2003; Mustafa, 2007; WAPDA, 1990), same time importance for development of new dams for water reservoirs or for hydro-electric generation and adopting water conservation measures has been highlighted. On the other hand, very few literature is available on the regional water management studies where interprovincial water conflicts are not even emphasized particularly which is the most controversial issue of current era (Memon, 2004). Similarly, water distribution has not only lowered agricultural production in the country but smaller provinces, i.e., Sindh, Khyber-Pakhtunkhawa (old name NWFP) and Balochistan, complaint that the largest province, i.e., Punjab is usurping their share of water (Baxamoosa, 2007; Talpur, 2001).

It is obvious that the attitudes towards water consumption vary across regions but this misconception can lead further in violent conflicts if serious attention has not been paid. Conflicts over water often emerge when different groups of people have different goals where the conflicting goals are common in water management scenarios.

Water resources management increasingly requires compromise and consensus if solutions to problems are to be formulated and implemented. As issues of competing uses intensify, water decision makers are increasingly called upon to manage people as well as the water resource itself.

Unfortunately in Sindh province, the current irrigation system suffers from the deteriorating infrastructure and weak governance so there is need to improve governance efficiency, reliability and equity of irrigation water distribution at watercourse levels and enhance the agricultural productivity. Thus, research emphasizes the deficiency in the literature on water resource allocation in the country in general and water resources geopolitics (Colombi and Robert, 2003), its distribution and impact in particular in Sindh. Moreover, this research is mainly descriptive in parts where greater emphasis has been would be paid to the hypothesis that inequitable water distribution not only created interprovincial conflicts but also became source of decline in agriculture in the country with many negative impacts.

Corresponding Author: Habibullah Magsi, UMR SAD-APT, INRA AgroParisTech 16, rue Claude Bernard, 75005 Paris, France 
Agric. J., 7 (6): 382-387, 2012

\section{INDUS WATER DISTRIBUTION AND MANAGEMENT}

Access to and control of water, depends primarily on the available technology and engineering feats such as river diversion structures, canals and dams. As growing human pressure on water resources brings actual water use closer to potential ceilings, societies usually respond by adopting conservation measures and by reallocating water towards more beneficial uses. The Indus is the lifeline of Sindh province of Pakistan. The river flows through the province on its way down from Punjab province, feeding numerous reservoirs and irrigation channels on the way but the lifeline is gradually waning (Baxamoosa, 2007). Sindh has been prone to some of the harshest droughts and lowest supplies of fresh water over the past 2 decades. Scant rainfall and politicization of water distribution to the provinces is leading to both economic and social hardship. Sindh has been at the bitter end of a raging controversy on water distribution.

According to the water accord in 1991, Sindh has to be allocated at least 48 Million Acre Feet (MAF) for both the Kharif (dry season) and Rabi (rainy seasons) but the province is receiving much more less share (IUCN, 2007). This has not only created an agricultural and social crisis in the province but has also politicized the issue to a great extent. A number of political groups have protested, claiming that other provinces are stealing their rightful share (Rinaudo, 2001). This also includes opposition towards the building of large and small dams/reservoirs upstream to control the flow of water. Sindh, being at the tail-end of the Indus, anticipates that these disputes will lead to even more limited supplies of water. There is an atmosphere of resentment among people of the province who is trying to avert an environmental catastrophe due to the ever-diminishing share of natural resources.

The management and distribution of the Indus water is a highly volatile issue between the four provinces of Pakistan in general but particularly it is the main source of conflict between Sindh and Punjab. The Indus river and its tributaries lie in the North of Punjab provine and flow through Pakistan into the Southern province of Sindh through the Indus delta until they meet the Arabian sea. Punjab is the upstream province; it is also the politically and demographically dominant (Nazir, 2008), therefore by all accounts, the province is in charge of decision-making in relation to water management and distribution; even though, Sindh is highly dependent on the Indus water (Fig. 1). The Punjab as the upstream riparian justifies its use and the management of Indus water on the basis of territorial sovereignty (Kaya, 1998). This theory of territorial sovereignty claims any state may use any

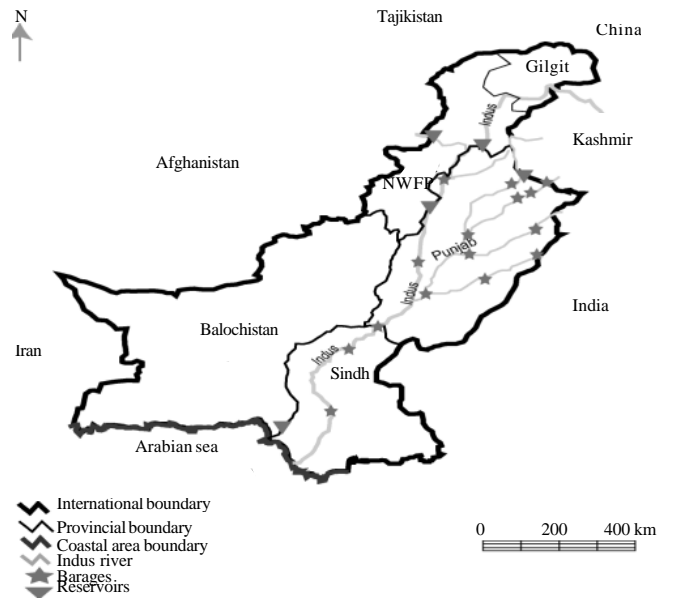

Fig. 1: Indus river flow through the provinces of Pakistan

watercourse within its borders as necessary without regard to downstream riparian. Conversely, Sindh as the downstream riparian promotes the theory of territorial integrity which indicates that downstream riparian have exclusive right to the natural, uninterrupted flow of the river from the territory of upstream riparian.

However, both theories are not adequate solutions to the water-sharing conflicts and neither has received much international support. International tribunals prefer to abide by the principle of equitable utilization (World Bank, 2005). This principle is grounded in territorial integrity and restricted sovereignty within a given river basin. According to this principle, a basin state's sovereign rights to the waters of international rivers within or adjoining its territory are limited by the corresponding sovereign rights of other basin riparian. This implies that a riparian state may utilize the water of a river basin to a limited extent so that this does not interfere with the reasonable utilization of other riparian (Kaya, 1998). In fact, sharing the waters of the Indus river basin is not so simple within the Pakistani context. The problem is that bitter relations have been built as a result of years of mistrust and miscommunication between the provinces. Sindh in particular feels that Punjab has deprived it of its historic rights to the Indus waters. Moreover, Punjab is viewed with contempt because of its dominant and dominating positions in politics, economy and the military by the other provinces.

It is quite clear that the River Indus is a pivotal water source for the Sindh (Fig. 1) as it is the only source of freshwater that sustains the people, environments and the economy of Sindh. The Indus river system comprises of seven rivers including the River Indus itself, the 5 rivers of Punjab: Bias, Sutluj, Ravi, Chanab and Jehlem, discharge in Indus at Mithan Kot and the Kabul 
Agric. J., 7 (6): 382-387, 2012

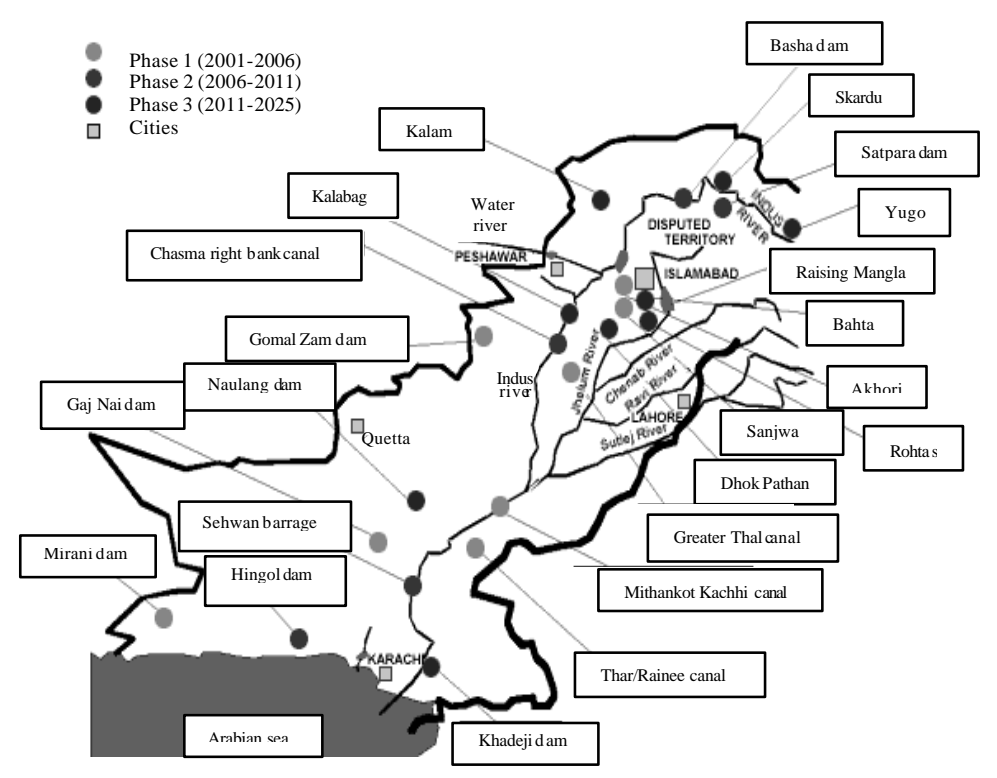

Fig. 2: Location map of water sector projects (WAPDA, 1990) (http://www.pakwapda.com/vision2025/ default.asp)

river at Attock (Fig. 2). As a matter of fact, Sindh is a gift of the Indus as most of the lower Indus basin that constitutes Sindh today is accumulation of the silt, deposited by Indus flood flows over both of its banks and down below where it discharges into the Arabian sea. Sindh its main source of water is the Indus river and is also home to the delta which absolutely dependent on the freshwater from the Indus. Without this freshwater, there would be no delta and no livelihoods where millions of fishing communities would be completely destroyed.

The negative impacts of large dams manifest in the long run and these are generally faced by those who live at the tail-end of the downstream riparian, known as the people of the delta. In Pakistan, the cost of development is paid by the people of the Indus delta in terms of the destruction of mangroves, depletion of fisheries, reduced drinking water supplies and devastation of their lives and livelihoods.

Present status of the water in Indus basin: Before partition of sub-continent India, there was only one barrage, i.e., the Sukkur barrage (built in 1932) on the River Indus. During last 64 years of independence there are now 19 barrages and 43 canal systems with 48 off-takes. The Indus river system in Pakistan, creating world's largest contiguous man made system of $61,000 \mathrm{~km}$ of canals and 105,000 water courses which irrigating about 35 million acres of land (WAPDA, 2008). Moreover, 3 big storage reservoirs were also built, Mangla on River Jehlum and
Tarbella and Chashma on River Indus with total storage capacity of $20 \mathrm{MAF}$. Additionally, 12 link canals were built to transfer water from Western rivers to Eastern rivers or the tributaries of the River Indus (Talpur, 2001). This activity has largely been carried out without any proper consent of Sindh province.

Moreover after many commissions and interim arrangements in 1991, an Indus River System Authority (IRSA) was established for the purpose of fair water distribution among the provinces. The total water available in this system was estimated to be $114.35 \mathrm{MAF}$ below rim stations. It was allocated as $55.95 \mathrm{MAF}$ for Punjab, 48.76 MAF for Sindh, 5.78 MAF for Pakhtunkhawa and 3.87 MAF for Baluchistan (Abbasi, 2002).

Water availability: Total availability of water is not enough in the system to entertain the luxury of so many projects on the Indus river system. The flow pattern of Indus rivers system is highly irregular. Annual average water availability during the period 1922-2007 has been 138.09 MAF where the super floods occur approximately once in 5 years only. This may increase the average to a respectable 137.27 $\mathrm{MAF}$ year $^{-1}$ but in the remaining 4 years availability of water is $123.59 \mathrm{MAF}$. Therefore, Kabul river contributes annual average of about $20 \mathrm{MAF}$ to Indus main. Thus, the water availability on annual average will reduce to $130.09 \mathrm{MAF}$ and after 5 years, it will go down to $116 \mathrm{MAF}$. On the other hand, supposed escape below Kotri barrage, based on post Tarbela period 
Agric. J., 7 (6): 382-387, 2012

Table 1: Reservoir's storage capacity and availability of water Storage capacity and availability (MAF)

\begin{tabular}{lccc} 
& \multicolumn{2}{c}{ Storage capacity and availability (MAF) } \\
Reservoirs & Initial & 2001 & 2025 expected \\
\hline Mangla & 5.3 & 4.4 & 4.0 \\
Chashma & 0.7 & 0.4 & 0.3 \\
Tarbela & 9.6 & 7.9 & 6.2 \\
Total & 15.6 & 12.7 & 10.5
\end{tabular}

Government of Pakistan (2008)

Table 2: Water scenarios in the Indus river sy stem

\begin{tabular}{lcc} 
Scenario & Annual & $\begin{array}{c}\text { Outflow to sea from } \\
\text { Kotri barrage }\end{array}$ \\
\hline Water availability (MAF) & 130.09 & 35 \\
Required commitment (MAF) & 146.90 & 48 \\
Outflow to sea from Kotri barrage & -16.81 & -13 \\
\hline
\end{tabular}

WAPDA (2008)

(1976-77 to 2002-03) is estimated to be $48 \mathrm{MAF}$ (WAPDA, 2008). The Indus water system summary is as shown in Table 1 and 2 .

Planning, storage and diversion activities: Under Vision-2025 program, Pakistan has planned numerous projects and approved them for construction without appropriate consultation or consent of Sindh as required under the agreements between Sindh and Punjab. These projects include Kalabagh, Basha, Sukurdu, Satpara, Dhok Pathan, Sanjwal, Akhori, Bhater, Rohtas, Yugo, Chiniot reservoir, Hingol, Naulang, Gajnai, Mol and Khadeji, Rohtas, Mirani dam, Sabakzai, Gomal Zam, Kalam dam, Kachhi canal, Chashma right bank canal, greater Thal canal, Rainee canal and Sehwan barrage (Fig. 2). As has been the practice in the past, most of these projects have been designed to benefit the upstream riparian only.

If the Vision-2025 is implemented as planned, the water will no more available in the lower basin even in the Kotri barrage (Kazi, 2004). If the situation is not reversed soon and the upstream continued diversion and storage, it is not farfetched to see an imminent ecological disaster in the lower Indus basin that would eventually create a famine situation in Sindh.

\section{IMPACTS OF WATER SHORTAGE}

In this study, researchers tried to figure out the detailed impacts of water shortage emanating in the province.

Socio-economic impacts: Katcho (flooded area) area is about 810,000 ha in the lower basin along the Indus which is flooded by Indus river. This area is rich in forests, grazing lands, poultry, animal husbandry, agriculture and fishing. About a million people were living there and were engaged in the timber trading, firewood supplying, fishing and boating. As the shortage of water is witnessed the economy of this area has been tremendously declined and resultantly the unemployment, migration to other areas and crime rate have been raised in this region.

With the reduction in Indus water flows, most of the rural Sindh is in a grip of severe economic downturn. People are unable to cultivate their lands due to lack of water and are quitting cultivation altogether as it is not profitable anymore. The decline in total cultivated area of 9.03\% has been estimated during 1972-1990 in Sindh due to shortage of water (Government of Pakistan, 2008). Due to continuous water storage, the costal ecosystem has been damaged. Results of a survey conducted in 2001 by the Government of Sindh indicated that $>486,000$ ha land were eroded or lost to the sea-water in Thatta and Badin districts, dislocating a quarter million people and inflicting financial losses $>2$ billion dollars. The seawater has destroyed at least one-third of the land (SAP-Pakistan, 2001).

Environmental impacts: Sindh is home to many natural lakes. Manchar, Kinjhar, Haleji, Hadero, Chotiari and many more small lakes are spread all over Sindh. Most of these are fed by Indus. These lakes and wetlands are being degraded at an alarming rate. The lakes in Sindh are an important source of drinking water, fish, agriculture and employment to many people (IUCN, 2007). The lakes are host to many species of birds, flora and fauna. Economic and aesthetic benefits drawn from the lakes are being lost due the shortage of water. Manchar, the largest lake in Sindh, there were 400 fish and 726 bird species documented before 1960 but up to 1999 there was only 70 fish and 100 bird species are left. Total bird population has reduced $40 \%$. Edible vegetables harvested in the lake have also reduced by $70 \%$ (Bughio, 1999).

The Indus water discharge to the Arabian sea keeps the sea water at bay and does not let it intrude into the surface but due to the shortage of water the salt-water intrusion has been witnessed up to $100 \mathrm{~km}$ North of the sea. This practice will continued until adequate water is released in Kotri downstream. Furthermore, seawater renders fertile agricultural lands as useless which results the economic devastation. Hundreds of villages in the Badin and Thatta districts have been migrated to some other areas (Kazi, 2004).

Ecological impacts: There are 242,830 ha of riverine forests along the banks of river Indus in Sindh has been adversely affected due to shortage of water. Out of 242,830 ha damaged forest, an area of about 17,115 ha 
was regenerated during the years 1995-98. A major damage to the natural habitat of many tree species was detected in the Sindh and wildlife in these forests is also threatened. The water shortage was the major reason for the loss of habitat. The deforestation followed by soil degradation, salinity and erosion that will then lead to desertification, rendering fertile lands to a barren desert Sindh Forest Department, 2002. Mangrove forests in the Indus Delta spread $>263,000$ ha and were the 6 th largest in the world. The water, nutrients and silt deposited by the Indus when it discharges into the sea, sustained the mangroves. The forests support many species of trees, wild life and fish and also, these forests keep the river silt from reaching shipping lanes in the sea closer to Karachi and Qasim seaports (Kazi, 2004).

Mangrove forests play a significant role in development of the fish that is caught near the Sindh coast. Inflow to the sea provides a channel for the migratory fish to swim upstream for spawning in the lower Indus basin. The annual catch of shrimps in Sindh was 27,541 ton that accounts 97 of total national catch but now has been reduced as $92 \%$. Other species like river turtle, frogs, birds and bees have also been hampered. Migratory fish such as Pallo and Barramundi have registered a significant decline (SAP-Pakistan, 2001). Therefore, the biodiversity in Sindh is at risk as biotic potential of many species is starting to be diminished and many of them may be lost forever if the environmental and ecological devastation due to water shortage is not properly controlled.

Cultural and health impacts: Water has great importance in the lives and belief system of the Sindhi people, the religion, literature and many cultural and social aspects of their lives are very much related with water because of this Sindhi are mostly known as Darya Panthis or the river worshipers. Many festivities, religious rites and social events are held at or around the water. These facts point to a special psyche of Sindhi's related to water. Fisher folks (Mohanas) mostly live around the rivers, the lakes and the coastal areas. Due to water shortage, the lives of these folks have been enormously disturbed which forced them to move away from and try to find alternative means of livelihood (Baxamoosa, 2007). It is not only devastating for these folks to adjust to a new way of life or location but also a great loss to the cultural diversity of Sindh.

The Indus civilization was the world's 3rd ancient civilization after the Egyptian and the Babylonian. The demise of this earliest known civilization on the earth was due to shifting of the mighty Indus. Due to the shortage of water, modern Indus is under tremendous pressure and its lower riparian migrating to other areas because of the destruction of the Indus river. Besides that the drinking water supplies have dwindled and degraded in quality in many parts of Sindh, due to the water shortage and the incidences of diseases related to drinking polluted water have increased like; kidney, stomach and intestine, eye and skin diseases. Due to the scarcity of water and resulting economic downturn has rose the unemployment, poverty, crime-rate and other social problems.

Political impacts: In the present state of environmental awakening and global acceptance of lower riparian rights, this situation may be seen as a great violation of the international norms because Sindh is already under tremendous repression from the central government. The water issue may become a source of dissatisfaction because the lower Indus basin is moving towards famine situations and ecological disaster. If a sincere effort is not taken to reverse the water shortage problems, the national aspirations of Sindh may then also be viewed as legitimate human rights issue (Memon, 2004).

\section{CONCLUSION}

There are many water projects instituted to store and divert Indus water in the upper Indus basin that is causing the water shortage in Sindh resulting in economic, social and ecological problems. If the sufficient water has not been released below the Kotri barrage to meet the demands of the Indus delta and the coastal region, slowly but surely Sindh will be moving towards an ecological disaster and famine like situation.

Fair Indus river system water policies should be developed and implemented based on valid Sindh-Punjab agreements to ban construction of any structures upstream until downstream needs of the lower Indus basin are met. A study should be conducted as visualized to the 1991 water accord to establish the downstream water needs. A new agreement should be developed that must recognize the internationally accepted lower riparian rights and ensure sufficient water availability in the lower basin and the ecological balance of the River Indus and the Indus delta. International monitoring and dispute arbitration should be included within the agreement to resolve disputes within the strategy of international laws.

\section{ACKNOWLEDGEMENTS}

Researchers would like to thank the anonymous reviewers. Researchers would also like to thank Andre Torre, Romain Melot and Hai-Vu Pham for their valuable comments on the earlier draft of the study. 


\section{REFERENCES}

Abbasi, A.G., 2002. Restoration of Sindh's primary rights over river Indus. Proceedings of the 18th Convention of SANA, July 4-7, 2002, Cherry Hill, NJ., USA.

Baxamoosa, S., 2007. Where the river runs dry: An analysis of the ecological and socioeconomic impacts of large dams on the Indus Delta. Ph.D. Thesis, School of Social Sciences Hampshire College, USA.

Bughio, A., 1999. Cries of Manchar. Hayatee Magazine, Sindh Graduates Association, Karachi.

Colombi, S.B. and W.B. Robert, 2003. Geopolitics, water and development in South Asia: Cooperative development in the Ganges-Brahmaputra delta. Geog. J., 169: 43-64.

Government of Pakistan, 2008. Statistical supplement of economic survey 2006-07. Ministry of Finance, Islamabad, Pakistan.

IUCN, 2007. Sindh strategy for sustainable development. Planning and Development Department, Government of Pakistan.

Kaya, I., 1998. The Euphrates-Tigris basin: An overview and opportunities for cooperation under international law. Conflict Resolution and Transboundary Water Resources, http:/ag.arizona.edu/OALS/ALN/aln44/ kaya.html.

Kazi, A.M., 2004. Overview of water resources in Pakistan. Proceedings of the National Seminar, 15-16 January 2004, University of Sindh Jamshoro, Pakistan.
Memon, A.A., 2004. Evaluation of impacts on the lower indus river basin due to upstream water storage and diversion. Proceedings of the World Water and Environmental Resources Congress, June 27-July 1, 2004, Salt Lake City, Utah pp: 9.

Mustafa, D., 2007. Colonial law, contemporary water issues in Pakistan. J. Political Geogr., 20: 817-837.

Nazir, M., 2008. The problems and issues of federalism in Pakistan. J. Pak. Vision, 9: 109-128.

Rinaudo, J.D., 2001. Corruption and water allocation: the case of public irrigation in Pakistan. Water Policy, 4: 405-422.

SAP-Pakistan, 2001. Water crisis in Pakistan (News clippings, reports, articles). A South Asia Partnership Report, May 4.

Talpur, M.A., 2001. Water shortage in Sindh: Causes and consequences. Sangat (SANA), 17: 9-11.

WAPDA, 1990. Water sector investment planning study. Federal Planning Cell, Lahore, Pakistan.

WAPDA, 2008. Ongoing projects. Water and Power Development Authority, Pakistan. http://www.wapda. gov.pk/htmls/ongoing-index.html.

World Bank, 2005. Pakistan's water economy: Running dry. The World Bank in Pakistan. http://www. worldbank.org. 